\title{
Food supply chains: Are efficiency and responsiveness mutually exclusive?
}

\author{
Sven Koops, Dr. Diane Mollenkopf and Prof. Tony Zwart \\ Commerce Division, Lincoln University, PO Box 84, 8150 Canterbury, New Zealand, Ph: +64-3-325-2811, Fax: +64-3-325-3847, \\ E-mail:koops@lincoln.ac.nz; mollenkd@lincoln.ac.nz; zwarta@lincoln.ac.nz
}

\begin{abstract}
This article presents the empirical results of a study of strategic change in 291 organisations operating in New Zealand food supply chains. Firms in food-related businesses have been increasingly responsive to changing customer demands and competitive pressures and have introduced substantial product and process changes. This research considers firm-internal and supply chain relationship characteristics as the cause of strategic change. Using structural equation modelling, significant relationships between firm resources and strategic change were sought. Multi-group analyses were used to identify moderating effects of supplier and customer collaboration. The results indicate that resources have an effect on product and process changes. Supplier and customer collaboration were not found to have any moderating effects. The results have important implications for both supply chains and firms in terms of strategic change and the benefits of supplier and customer collaboration.
\end{abstract}

Key words: resources, strategic change, structural equation modelling, supply chain collaboration,

\section{Introduction}

Firms in New Zealand food supply chains are making considerable strategic changes to the range of food products they offer, and the processes or operations they employ. Tracking strategic changes of meat processing firms over a period of two years revealed that some tended to pursue product changes while others implemented process changes aimed at lowering the cost of production. For example, one New Zealand meat-processing firm revealed that its relationship with a key customer in Great Britain was behind the introduction of a new organic product line. However, to procure organic supplies the firm had to form new supplier relationships with Patagonian farmers. In contrast, another meat processor focused on implementing quite considerable process changes that were designed to lower the costs of production and support its close relationship with suppliers.

Why some firms follow product-change strategies while others pursue cost efficiencies is not readily apparent. Scholarly works in the fields of strategic orientation and resource dependence have addressed this issue but an additional perspective is called for. The recent trend towards more integrated supply chains (Barkema \& Drabenstott 1995; O'Keeffe 1998) suggests that firms' relationships with customers and suppliers can significantly impact their strategic decisions to pursue product changes and/or cost efficiencies. This appears to be relevant to the examples presented above as well. Fisher (1997) suggests that all firms in a supply chain need to pursue the same objectives. If a firm's suppliers were to focus on low cost production while customers focused on the introduction of new products, neither the supply chain nor the firms would be able to compete effectively because their strategies worked at cross purposes (Treacy \& Wiersema 1995). In turn, this would constrain the achievement of their individual corporate objectives. Even if firms are strategically aligned, rigid structures and resource constellations could inhibit strategic change (Leonard-Barton 1992) that may be necessary to achieve corporate objectives.

Considering the product-change strategy versus the costefficiency strategy poses an apparent paradox. Cooper et al. (1997) propose that supply chains need to achieve high levels of integration to deliver better value to customers by minimising costs. Any activity that adds costs that customers are not prepared to pay for needs to be eliminated. However, Fisher (1997) suggests that supply chains that are designed in such a way will not perform effectively when they have to respond to new customer needs. Consequently, he suggests that supply chains trade-off' 'low cost production' for 'responsiveness to customer needs'. We argue that this particular focus is spurious because firms are not bound to their supply chains irrevocably, as demonstrated with the earlier examples. Instead, attention should focus on firms' relationships with their suppliers and customers and the impact these relationships have on whether and how firms make strategic trade-off decisions. Do firms integrate operations and processes with their customers/suppliers in order to become more responsive to end-customer needs, or do they integrate for purposes of efficiency to drive costs out of the supply chain? Does integration in itself create rigidity within supply chains that inhibits radical product and/or process changes? Thus, the more interesting issue is to address the bounds on responsiveness- and efficiency-driven initiatives. 
The previous discussion identifies two important issues associated with strategic change. Firstly, it appears that existing relationships with customers and suppliers can affect the strategic options of individual firms with respect to product and process changes. Secondly, it appears that strategic product-mix and process changes can influence firms' relationships with suppliers and customers. Therefore, the objective of this study is to understand better the role that supply chain relationships play in supporting or inhibiting strategic change, and to understand when strategic change is likely to cause changes to the supply chain. Since supply chain relationships are unlikely to be the sole factor in strategic change decisions, but rather one important dimension among others, relevant firm-level factors must also be considered. Consequently, this study seeks to identify (a) factors that lead to considerable strategic product and process changes, (b) the effect of existing customer and supplier relationships on these strategic changes, and (c) the effect of these strategic changes on relationships with customers and suppliers.

Strategic product-mix and process changes are driven by corporate strategy that creates the framework for a firm's activities in relation to product markets, growth objectives, and sources of competitive advantage (Ansoff 1968; Drucker 1973). Selznick (1957) proposes that firms possess distinctive competencies that enable them to develop competitive positions versus competitors. That is, they have specific competencies other firms do not have but which enable them to perform better than competitors. Additionally, changing environments give rise to opportunities and threats, such that firms use their competencies to avoid those threats or to maximise opportunities (Learned et al. 1969). The resource-based view of the firm advocates that firms identify those distinctive competencies or resources that provide them with a competitive advantage, on the basis of which they make strategic decisions (Wernerfelt 1984).

When firms make product-market and growth decisions they have to appraise their resources because resources are semi-permanently coupled with organisations (Barney 1991; Grant 1991; Hansen \& Wernerfelt 1989). Consequently, firms that have a clear understanding of their resources can leverage these into new activities (Prahalad \& Hamel 1990). On the other hand, an exclusive focus on existing resources can become problematic for firms when resources lose the basis for a competitive advantage (Hart 1995), as can be the case when environmental changes result in past strengths to become current weaknesses. Thus, firms need to constantly develop new resources or adapt existing ones. Firms can accomplish this if they have dynamic capabilities which enable them to change or adapt their resources "...to create new products and processes, and respond to changing market circumstances" (Teece \& Pisano 1998, p.197). Consequently, in the absence of dynamic capabilities new activities that firms might perform will be closely related to those activities that firms already perform (Leonard-Barton 1992).

\section{Model development and hypotheses}

Strategy can be viewed as a process of leveraging resources and capabilities to develop new opportunities that sustain competitive advantage by meeting customer demands more effectively than competitors can (Hamel \& Prahalad 1994). Two common strategies used to meet customer needs are to develop differentiated products or to develop a cost leadership advantage (Day \& Wensley 1988; Porter 1980). Differentiation refers to the process by which firms continuously improve their product mix to better meet customer needs (Day 1994). In this study, we describe such a strategy as responsiveness. Cost leadership, on the other hand, implies an efficiency perspective that emphasises a low-cost focus in internal processes and operations of the firm. To maintain such an advantage, firms needs to continuously improve operations and processes in order to sustain potential advantages (Johnson \& Scholes 1999). Building on the resource-based view of the firm, the literature suggests that three types of resources can affect a firm's strategy. Firstly, tangible and intangible assets are resources that firms own or trade (Hall 1993). Assets are used in the production of products and include property, plant and equipment, patents, licenses, technology know-how, brand names, etc. (Amit \& Shoemaker 1993; Barney 1991). Some assets are likely to enable firms to make product changes (e.g. brand names) while others are more likely to influence process changes (e.g. patents). Secondly, capabilities are "complex bundles of skills and accumulated knowledge, exercised through organizational processes that enable firms to coordinate activities and make use of their assets" (Day 1994, p. 39). Capabilities refer to organisational processes in terms of the specific functions that firms need to perform, such as marketing, distribution, production, etc. Thirdly, dynamic capabilities enable firms to reconfigure and transform assets and capabilities. As such, collaboration with customers and suppliers can help firms develop new resources or restructure existing resources and thus gain a competitive advantage (Teece \& Pisano 1998).

Because resources are complex, yet, coherent constellations of assets, capabilities, and dynamic capabilities it is unlikely that a single resource constitutes a sustainable competitive advantage (Amit and Shoemaker 1993). We have, therefore, conceptualised assets and capabilities in terms of their implication for strategic outcomes of product mix changes or process changes. Table 1 identifies assets and capabilities 
incorporated in this study, as they are thought to relate to such strategic change.

Initial hypothesis development centered on the constellation of assets and capabilities thought to influence process and product-mix change, as presented in Table 1. However, preliminary factor analysis identified that the assets and capabilities measured did not factor into the functional groups as foreseen. Instead, they factored into three factors identified as Marketing Capabilities, Technology Capabilities and Assets. The initial variables relating to capabilities and assets are presented in the appendix, along with the factor scores of the resulting variables used in the analysis. For simplicity, hypotheses are summarised in Table 2 according to the revised variables.

Table 1. Resources and capabilities related to process vs. product mix strategic change.

\begin{tabular}{lll}
\hline & Process change & Product-mix change \\
Assets & $\begin{array}{l}\text { specialised plant and equipment } \\
\text { patents, technology know-how }\end{array}$ & brands, trademarks \\
Capabilities & $\begin{array}{l}\text { operations planning } \\
\text { production technology } \\
\text { R\&D } \\
\text { work force }\end{array}$ & $\begin{array}{l}\text { customer needs focus } \\
\text { distribution } \\
\text { purchasing }\end{array}$ \\
& supplier collaboration & \\
\hline Dynamic capabilities & customer collaboration \\
\hline
\end{tabular}

Based on conceptualisations by Day (1994), Porter (1980), and Teece and Pisano (1998)

Table 2. Summary of hypotheses.

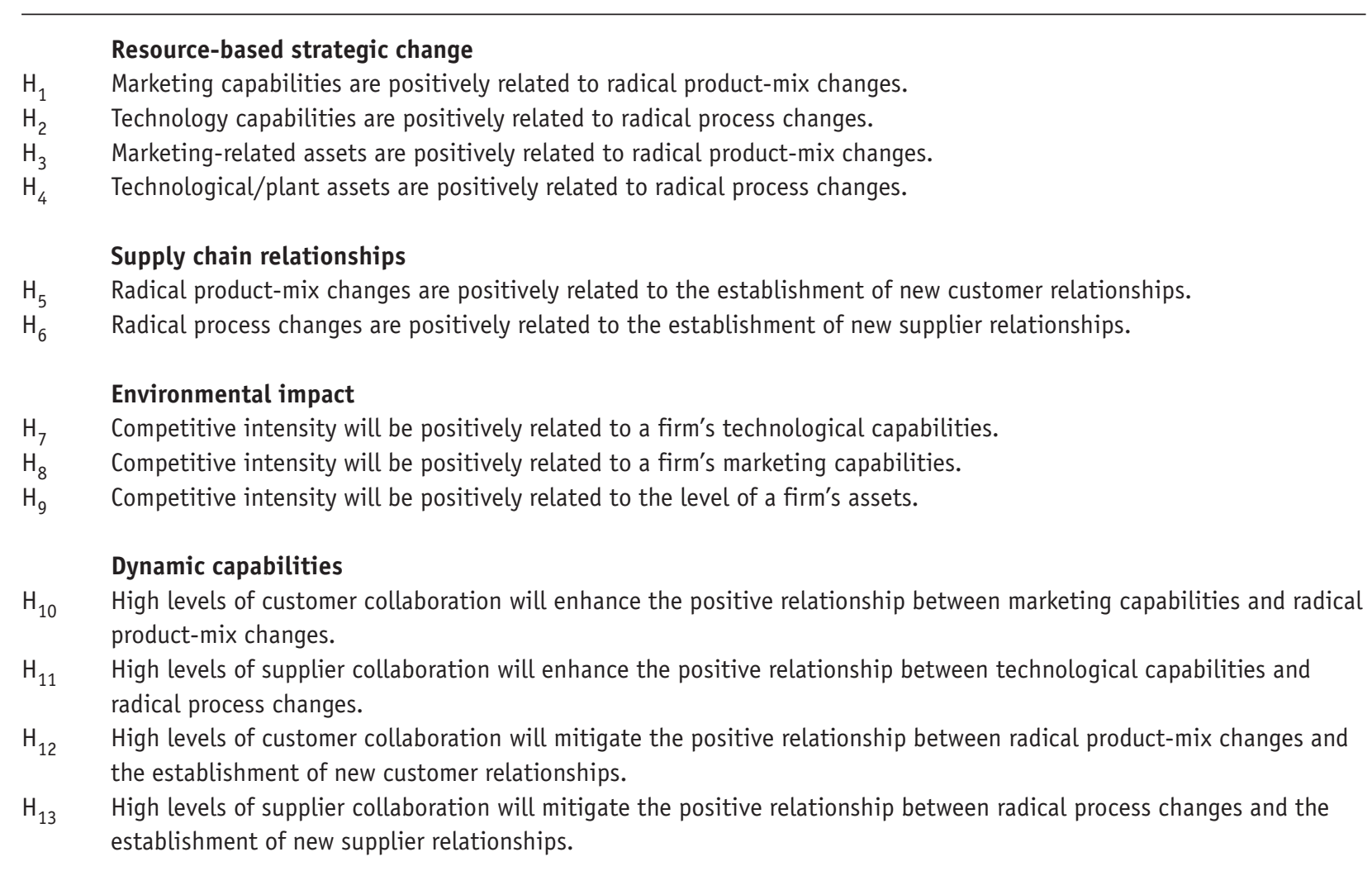


Marketing capabilities are thought to influence producemix changes, while technology capabilities are expected to influence process changes. Because assets were initially envisioned in two groups, related to both product-mix and process changes, a revised asset hypothesis suggests that assets are positively related to both product-mix and process change. Radical product-mix and process changes are often associated with diversification, market-expansion, and other growth objectives, which may necessitate new supply chain relationships (Ansoff 1968). Therefore, process changes are expected to influence the creation of new supplier relationships while product-mix changes are expected to result in new customer relationships.

The level of competition in an industry can affect whether firms make product and process changes. As competition increases the availability of alternative products for customers also increases (Kohli and Jaworski 1990) and firms come under pressure to change their product-mix or lower prices (Porter 1980). How firms respond depends on the assets and capabilities, which provide firms with a competitive advantage. Consequently, as the level of competition increases firms will consider their particular assets and capabilities as increasingly important. Therefore, competitive intensity is expected to be positively associated with a firm's capabilities and asset base.

Dynamic capabilities are not about what assets firms have or what functions they perform but how assets or the performance of certain functions may be changed or adapted, in order to be used differently. Thus, the dynamic capabilities of customer and supplier collaboration are expected to positively moderate the relationship between a firm's capabilities/assets and strategic changes, and to mitigate the relationships between strategic changes and new supply chain relationships. All hypothesised relationships are shown in Figure 1 and summarised in Table 2.

\section{Method}

A mail survey was conducted among firms involved in the processing (from a primary production level onwards), manufacture, distribution, or sale (wholesale and/or retail) of food products. Senior managers were targeted because of their overall knowledge of the practices and competencies of all aspects of their business.

The questionnaire was thoroughly pre-tested, which involved: feedback from practitioners and academic experts, a pilot test and data analysis on the initial items to test for measurement reliability. Items were randomized and a third were reverse-coded.

Scales for the predictor variables were in seven-point format ranging from "strongly disagree" to "strongly agree". Items were worded in terms of the importance of capabilities, assets, and dynamic capabilities when general strategic changes are made by the firm. Dependent variables were measured in a multiple-choice format using a seven-point scale ranging from "no change or very minor change" to "very major change" and included a column labelled "n.a." (not applicable).

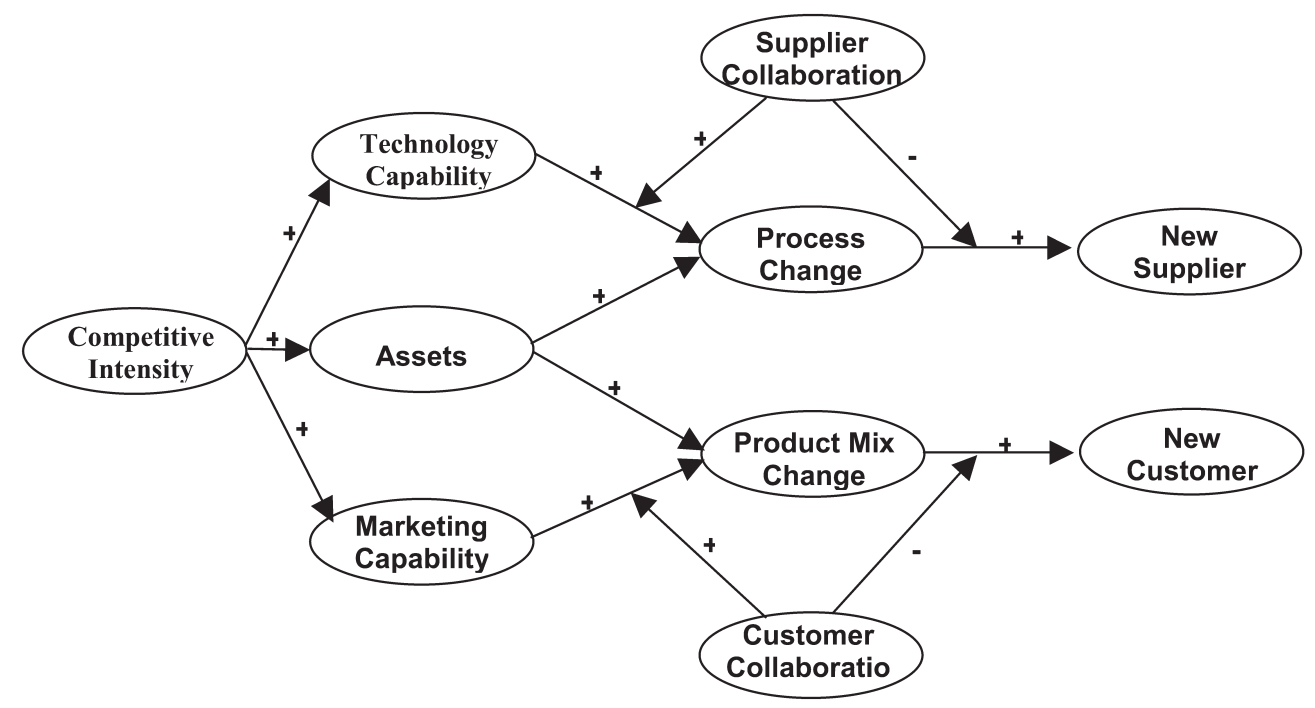

Figure 1. Hypothesised model. 
Mail procedures for the final instrument were based on those suggested by Dillmann (1978). In total, 1,025 surveys were mailed to New Zealand firms; 291 usable responses were returned, for an effective response rate of 28.4 per cent. To operationalise the constructs, several capability/asset areas in which firms can develop competitive advantages were identified in the literature: purchasing (Ragatz et al. 1997; Wisner \& Tan 2000), production/operations (Suarez et al. 1995; Vickery et al. 1993), work force (Suarez et al. 1995), technology (Suarez et al. 1995), R\&D (Gupta \& Wilemon 1996; Gupta et a.. 2000), distribution (Vorhies \& Harker 2000), identification of customer needs (Vorhies \& Harker 2000), and both physical and intangible assets (Amit \& Shoemaker 1993; Barney 1991). In most instances similar distinctions between responsiveness- and efficiencyorientations were made in these studies. Items were developed for the functional and asset resources based on these studies. Measures for collaboration with customers and suppliers were adapted from the Michigan State University Supply Chain 2000 Research Survey (Bowersox et al. 1999). Self-developed items were generated to measure strategic change because of the particular aspect of strategic change addressed in this research. Four single-item responses for the two aspects of strategic change and the two aspects of relationship change were used, as presented in the appendix. Alreck and Settle (1995) provide support for this approach, suggesting that it is acceptable that past actions or behaviours (as opposed to attitudes or perceptions) are measured with multiple-choice single item responses, provided the options are mutually exclusive and comprehensively exhaustive.

\section{Data analysis and results}

\section{Measurement model}

Preliminary factor analysis (principal axis factoring, according to Sharma, 1996) was conducted for all multi-item measures. The analysis of capabilities and asset items resulted in a three-factor solution, as previously indicated, corresponding to technology capabilities, marketing capabilities and a general asset factor. A two-factor solution emerged for the dynamic capabilities of supplier collaboration and customer collaboration, and a single factor emerged from the environmental measures relating to competitive intensity. Factor solutions and corresponding reliability scores for the resulting factors are presented in the appendix. These factors are represented visually in Fig. 1, and were used in subsequent hypothesis testing.

Hypothesis testing and model assessment was conducted using EQS 5.7b (Bentler and $\mathrm{Wu}, 1995$ ) for structural equation modelling. The two step approach suggested by
Anderson and Gerbing (1988) was used to estimate the measurement model separately before estimating it simultaneously with the structural model. The measurement model analysis was based on modification indices (Lagrange Multiplier or LM test), standardised residuals, and theory as a basis for respecifying the model. While several models proved to be similar in terms of goodness of fit indices, the final model represented the most parsimonious option. The absolute fit measures indicate the correspondence between actual and predicted covariance matrices. They were all within the acceptable range $\left(\chi^{2}=155.84\right.$, d.f.122, $\mathrm{p}=0.02 ; \mathrm{GFI}=0.94 ; \mathrm{SRMR}=0.049$; $\mathrm{RMSEA}=0.038 ; 90 \%$ confidence interval in EQS: 0.023-0.050). Next, incremental fit indices which indicate the fit relative to the null model were assessed and also considered acceptable (AGFI $=0.92$; $\mathrm{NNFI}=0.95 ; \mathrm{NFI}=0.87$ ). Parsimonious fit indices evaluate the fit of the model relative to the number of estimated coefficients. Again, they were also quite acceptable (CFI=0.96; IFI=0.96). The overall model goodness of fit is given by the normed $\chi^{2}$, which was in the acceptable range of 1.0 to 2.0 (1.28). These results suggest that the model can be accepted.

Next, the scales were tested for unidimensionality, composite reliability, and convergent and discriminant validity (Gerbing and Anderson 1988). The preliminary factor analysis mentioned previously established unidimensionality. Loadings were close to or above 0.5 with no crossloadings larger than 0.25 . The magnitude of the residuals was low and the majority of modification indices were below 3.84 in the overall model, further indicating unidimensionality (Sujan, et al. 1994). Reliability for all items of a construct (Table 3 ) was assessed by calculating the composite reliability and variance extracted (Hair, et al. 1995). Acceptable reliability is achieved at values 0.7 and above for established scales and 0.6 for new scales (Nunnally 1978) and variance extracted should be at least 0.5 (Fornell \& Larcker 1981). All variables are close to that level. The path coefficients from latent constructs to manifest items were all significant at $\mathrm{p}=<.01$ indicating convergent validity of all variables. Discriminant validity was achieved because correlations among the latent constructs were significantly less than 1 (Dillon \& Goldstein 1984) and average variance extracted for each construct is larger than the shared variance with any other construct (Fornell \& Larcker 1981).

\section{Structural model}

The structural model was then assessed simultaneously with the measurement model, ignoring the proposed moderation effect of the dynamic capabilities of customer collaboration and supplier collaboration. A nested approach 
Table 3. Construct means, standard deviations, squared latent factor intercorrelations, reliability estimates, and variance extracted.

\begin{tabular}{lllll}
\hline & $\begin{array}{l}\text { Technology } \\
\text { capabilities } \\
\left(X_{1}\right)\end{array}$ & $\begin{array}{l}\text { Assets } \\
\left(X_{2}\right)\end{array}$ & $\begin{array}{l}\text { Marketing } \\
\text { capabilities } \\
\left(X_{3}\right)\end{array}$ & $\begin{array}{l}\text { Competition } \\
\text { intensity } \\
\left(X_{4}\right)\end{array}$ \\
Mean & 4.34 & 4.93 & 5.49 & 5.56 \\
Std. Dev. & 1.49 & 1.68 & 0.88 & 1.15 \\
$X_{1}$ & 0.77 & & & \\
$X_{2}$ & 0.44 & 0.62 & 0.61 & \\
$X_{3}$ & 0.20 & 0.15 & 0.09 & 0.68 \\
$X_{4}$ & 0.02 & 0.10 & 0.61 & 0.67 \\
Composite Reliability & 0.76 & 0.66 & 0.48 & 0.47 \\
Variance Extracted & 0.54 & 0.50 & & \\
\hline
\end{tabular}

${ }^{*}$ Coefficient alphas are reported in the diagonal.

** Discriminant validity is obtained if $\rho_{\mathrm{vc}(\eta)}>\gamma^{2} ; \rho_{\mathrm{vc}(\eta)}$ is the variance extracted for a construct, and $\gamma^{2}$ is the squared latent factor correlation between a pair of constructs.

was employed, comparing the fit of the hypothesised model to a saturated model and an independence model. Results indicate that the theoretical model did not provide the best fit of the data. Alternate models were then tested, using sequential chi-square tests to evaluate each alternative. The final model exhibits an acceptable fit across a range of indices (see Table 4). Interestingly, this model includes several significant paths that had not been explored conceptually and thus were not hypothesised: a firm's marketing capability is positively related to its technology capability, and assets are positively related to both marketing capability and technology capability. These additional relationships will be discussed later. Standardised structural coefficients and coefficients of determination are shown if Table 5, which summarises the hypothesised main effects. The findings indicate support for $\mathrm{H}_{1}$ as marketing capabilities are related positively to product-mix changes (gamma $=0.634, \mathrm{p}<.01$ ) explaining $40 \%$ of the variance in product change. $\mathrm{H}_{2}$ is supported because Technology Capabilities (gamma $=0.487, \mathrm{p}<.01$ ) are positively related to process change, explaining $24 \%$ of the variance in process change.

Table 4. Model comparisons.

\begin{tabular}{|c|c|c|c|c|}
\hline Statistics & $\begin{array}{l}\text { Null } \\
\text { model }\end{array}$ & $\begin{array}{l}\text { Hypothesised } \\
\text { model }\end{array}$ & $\begin{array}{l}\text { Final } \\
\text { model }\end{array}$ & $\begin{array}{l}\text { Saturated } \\
\text { model }\end{array}$ \\
\hline Chi-Square & 1330.85 & 292.75 & 155.84 & 147.75 \\
\hline$P$ value & $<.01$ & $<.01$ & 0.021 & 0.033 \\
\hline d.f. & 153 & 123 & 122 & 126 \\
\hline NFI & & 0.76 & 0.87 & 0.88 \\
\hline NNFI & & 0.79 & 0.95 & 0.95 \\
\hline CFI & & 0.83 & 0.96 & 0.96 \\
\hline IFI & & 0.84 & 0.96 & 0.96 \\
\hline GFI & & 0.90 & 0.94 & 0.94 \\
\hline AGFI & & 0.86 & 0.92 & 0.92 \\
\hline SRMR & & 0.1 & 0.049 & 0.045 \\
\hline RMSEA & & 0.074 & 0.038 & 0.037 \\
\hline 90\% C.I. & & $0.064-0.084$ & $0.023-0.050$ & $0.021-0.049$ \\
\hline
\end{tabular}


Table 5. Main effects results.

\begin{tabular}{|c|c|c|c|c|c|}
\hline $\mathrm{H}_{0}$ & Path to & Path from & $\begin{array}{l}\text { Standardised } \\
\text { Structural } \\
\text { coefficient }\end{array}$ & $\begin{array}{l}\text { Significance } \\
\text { (1-tail) }\end{array}$ & $\mathrm{R}^{2}$ \\
\hline 1 & Product-mix change & Marketing capabilities & 0.634 & $<.01$ & 0.40 \\
\hline 2 & Process change & Technology capabilities & 0.487 & $<.01$ & 0.24 \\
\hline 5 & Customer change & Product-mix change & 0.569 & $<.01$ & 0.32 \\
\hline 6 & Supplier change & Process change & 0.437 & $<.01$ & 0.19 \\
\hline 7 & Technology capabilities & Competitive intensity & $-0.256^{+}$ & $<.01$ & 0.64 \\
\hline None & Technology capabilities & Assets & 0.671 & $<.01^{*}$ & \\
\hline None & Technology capabilities & Marketing capabilities & 0.306 & $<.01^{*}$ & \\
\hline 8 & Marketing capabilities & Competitive intensity & 0.269 & $<.05$ & 0.24 \\
\hline None & Marketing capabilities & Assets & 0.345 & $<.05^{\star}$ & \\
\hline 9 & Assets & Competitive intensity & 0.233 & $<.05$ & 0.054 \\
\hline
\end{tabular}

*a 2-tail test was used on unhypothesised relationships, as a more conservative measure of significance.

+The figure reported here is the direct effect which is calculated by subtracting the indirect effect (via the path: competitive intensity $\rightarrow$ marketing capability $\rightarrow$ technology capability) from the total effect. In this case the indirect effect is 0.263 $(p<.01)$. Consequently, the total effect is close to zero and non-significant. This is also referred to as a special case of the suppressor effect (see Tzelgov and Henik 1991).

Product-mix changes are related positively to customer changes (beta $=0.569, \mathrm{p}<.01, \mathrm{R}^{2}=0.32$ ) lending support to $\mathrm{H}_{5}$. Likewise, process changes are related positively to supplier changes (beta $=0.437, \mathrm{p}<.01, \mathrm{R}^{2}=0.19$ ), thus lending support for $\mathrm{H}_{6}$.

Competitive intensity was found to be positively related to both marketing capability (beta $=0.269, \mathrm{p}<.05$ ) and assets (beta $=0.233, \mathrm{p}<.05$ ) thus supporting hypotheses $\mathrm{H}_{8}$ and $\mathrm{H}_{9}$. The hypothesised direct relationship between competitive intensity and technology capability $\left(\mathrm{H}_{7}\right)$ cannot be supported. While the gamma coefficient reported in Table 5 is negative the total effect is virtually zero indicating that competitive intensity has no relationship to technology capabilities.

The positive relationship between a firm's marketing capability and its technology capability (beta $=.306, \mathrm{p}<$ .01 ) represents an unhypothesised finding that significantly improves model fit, and was thus included in the structural model. Two additional relationships are also included in the reduced structural model. Assets were found to be positively related to both marketing capability (beta $=0.345, \mathrm{p}<.05$ ) and technology capability (beta $=0.671, \mathrm{p}<.01$ ). These findings are interesting, given that the hypothesised direct relationships between assets and product-mix change $\left(\mathrm{H}_{3}\right)$ and process change $\left(\mathrm{H}_{4}\right)$ were not supported. These will also be discussed later.

Next, the hypothesised moderating effects of customer and supplier collaboration were incorporated into the analysis.
The data were split at the mean, into two approximately equal subgroups of low and high levels of customer/supplier collaboration, and used in consecutive analyses. To assess the moderating effect of customer collaboration, only the hypothesised structural paths were allowed to vary across the high and low groups. The Lagrange Multiplier (LM) test in EQS indicates for each constrained path the reduction in $\chi^{2}$ if the path were released to be estimated freely for each subgroup. The LM test did not suggest that any paths should be released. That is, for every path the reduction in $\chi^{2}$ is not large enough to improve overall model fit significantly. This suggests that the structural paths for the low and high groups are equal. The same process was carried out to test for the moderating effects of supplier collaboration, with similar results (Table 6). Therefore, none of the hypotheses relating to customer or supplier collaboration can be supported $\left(\mathrm{H}_{10}-\mathrm{H}_{12}\right)$.

\section{Discussion}

The results confirm that those capabilities that firms perceive to be important in their organisations affect the type of strategic changes they make. As firms' marketing capabilities increase in importance product-mix changes become more substantial, and as technology capabilities increase in importance firms make more substantial process changes. Additionally, product-mix changes tend to result in the formation of new customer relationships, while process 
Table 6. Moderating effects of supplier and customer collaboration.

\begin{tabular}{|c|c|c|c|c|c|}
\hline \multirow[t]{2}{*}{ Path to } & \multirow[t]{2}{*}{ Path from } & \multirow[t]{2}{*}{$\mathrm{H}_{0}$} & \multicolumn{2}{|c|}{ Standardised structural coefficients } & \multirow[t]{2}{*}{$\chi^{2}$ difference test } \\
\hline & & & Low & High & \\
\hline & & & \multicolumn{2}{|c|}{ Supplier collaboration } & \\
\hline Supplier changes & Process changes & $\mathrm{H}_{13}$ & $0.482 * *$ & $0.331^{*}$ & n.s. \\
\hline \multirow[t]{2}{*}{ Process changes } & Technology capabilities & $\mathrm{H}_{11}$ & $0.484^{* *}$ & $0.471^{* *}$ & n.s. \\
\hline & & & \multicolumn{2}{|c|}{ Customer collaboration } & \\
\hline Customer changes & Product -mix changes & $\mathrm{H}_{12}$ & $0.533 * *$ & $0.614^{*}$ & n.s. \\
\hline Prod-Mix changes & Marketing capabilities & $\mathrm{H}_{10}$ & $0.580 * *$ & $0.437^{*}$ & n.s. \\
\hline
\end{tabular}

* significant at $\mathrm{p}<.05$

** significant at $\mathrm{p}<.01$

n.s. = not significant

changes are more likely to result in new supplier relationships being developed. While these findings might suggest that firms do indeed pursue either efficiency or responsiveness strategies, other findings in this study suggest that a deeper understanding can be gained. It is the underlying capabilities that bring about strategic changes that are of most interest and the relationship between marketing and technology capabilities suggests that the trade-off is not an either/or situation of being either responsive or efficient, but that firms can and do pursue both strategies.

Because this finding was unexpected, possible response bias was investigated. Perhaps respondents indicated that either all their capabilities were important or all were not important in their organisations. Analysis suggests, however, that such a bias is not present in the data, because a high correlation between product changes and process changes (latent factor correlation $=0.895$ ) was found. If respondents' answers were biased we would expect to see relationships between marketing capabilities and process change, and technology capabilities and product change. However, a re-specified model (not presented in Table 4) including these paths did not improve overall model fit, and neither of the paths was statistically significant. Instead, we interpret this finding to corroborate other research that also implies that firms can pursue a hybrid of responsive- and efficiency-based strategies (Slater \& Narver 1993; Snow \& Hrebiniak 1980). Additionally, respondents were asked to consider strategic changes during the previous two year period. Therefore, we cannot treat product-mix and process changes as being related to a single event. Instead, our findings suggest that firms may at times pursue responsive strategies while at other times pursuing efficiency strategies. In either case, it is not surprising then that a marketing and technology capability are related, indicating that firms do realise the importance of being both responsive and efficient as a means to competing effectively. Recent literature on the importance of a dual achievement of operational effectiveness and best practice, and responsiveness to customer demands supports these findings (Porter 1996). Interestingly, assets were found to have no direct relationship with either product-mix or process changes, but do seem to play a role in a firm's strategic initiatives by being positively associated with both technology capabilities and marketing capabilities. Although the lack of direct relationship to either type of strategic change was unexpected, Teece \& Pisano (1998) have described assets as resources that support current organisational activities. Consequently, for assets to support new activities they need to be transformed or restructured by employing the firm's capabilities and dynamic capabilities. That is, the mere possession of assets is not the critical consideration, but rather it is how assets are used that is important in strategic change decisions.

The lack of findings on the moderating role of a firm's dynamic capabilities relative to the hypothesised capability - strategic change relationship was disappointing. This implies that collaboration does not enhance the relationships between firms' perceived capabilities and strategic changes, but rather that firms make strategic product and process decisions independent of their existing relationships with suppliers and customers. This lack of a moderating effect suggests that collaboration may not improve responsiveness to environmental change (both in terms of process and product-mix changes). Firms that collaborate with their trading partners may not be better 
off than firms that do not collaborate. Thus, firms that do collaborate need to ensure that they understand why they collaborate and whether collaboration has the desired effects. The benefits of collaboration should always be weighed against the disadvantages of collaboration (Ellram 1991).

Nor do collaborative relationships appear to moderate the relationships between a firm's strategic change and development of new relationships. The lack of findings about a firm's collaborative relationships suggests that collaboration with customers and suppliers does not necessarily lead to more stable or lasting relationships that can support product-mix or process changes. This seems to suggest that firms do not trade off integration for either responsiveness or efficiency purposes. Firms seem to form new relationships whenever necessary, and do not appear to be limited by their relationships. Since they also make their strategic decisions independent of their customers and suppliers, firms do not make a trade-off, they simply form new relationships to implement product-mix and process changes whenever necessary. This part of our discussion must be considered as a tentative attempt to interpret the lack of findings relative to our initial purpose of addressing the bounds on responsiveness- and efficiencydriven strategic changes.

\section{Implications, limitations and future research}

The discussion thus far leads to several managerial implications that need to be addressed. First, this research has attempted to ascertain important resource constellations in relation to their impact on both product-mix and process changes. The relationship between the constellations relating to technology capabilities and marketing capabilities underscores the complex nature of resource constellations. Thus managers need to be aware that their resource bases do not exist or operate in isolation of each other. Initiatives to improve either efficiency or responsiveness processes must consider the interrelated nature of the resource base. Second, managers operating in highly competitive environments face many challenges that can be best addressed by once again recognising the complexity of the resource base. For example, a strategic initiative to improve operational efficiencies should not ignore customer requirements and should, in fact, incorporate marketing capabilities into the strategic change process due to the inter-relatedness of these two core capability bases.

Third, while the role of a single asset factor was somewhat surprising the results agree with Teece and Pisano's (1998) assertion that assets are related to current activities, not new activities. Assets create path dependencies in terms of future activities firms are likely to pursue. However, firms can significantly diverge from that path if they cultivate and develop their marketing and technology capabilities. Fourth, while collaboration does not appear to enhance the relationships between a firm's capabilities and its strategic changes, it must be remembered that this study focused on collaboration only in relation to product-mix and process changes. There are many reasons that firms collaborate, but this research provides no evidence that such collaboration leads to significant strategic changes. In a similar vein, the lack of detected moderating effect of collaboration on the development of new supply chain relationships does not minimise the importance of supply chain integration as a viable business strategy. If indeed existing collaborative relationships are not supportive of strategic change, this would indicate that supply chains can only support existing activities, with little capacity to make significant process and/or product-mix changes within the context of existing relationships. However, this rather severe allegation should be seen in context of the purpose of collaboration. Even if collaboration is focused on optimising the alignment of current activities between supply chain participants (which was not tested in this research), the fact that firms tend to form new relationships whenever they make significant product-mix and/or process changes does not make collaboration superfluous. Managers are encouraged to maintain this perspective when evaluating the worth and purpose of developing collaborative relationships with supply chain partners.

The supply chain literature on collaborative relationships clearly indicates that firms collaborate with an orientation towards future activities (Dyer and Singh 1998). Since this notion was not supported in the current research, this is clearly an area for future research activity. This is particularly the case in environments characterised by intense competition and rapidly changing customer needs. In such cases, strategic product-mix and process changes will become increasingly frequent. Managers need to consider whether the time and investment necessary to develop such relationships are worth the risk of the relationships dissolving as change occurs. Further research needs to clarify this issue so as to provide more guidance for managers. Additionally, the notion of collaboration was treated quite generally in this research. This limitation may have affected our results, and future research needs to focus on more specific types of supply chain collaboration to gain a more holistic view on the role of collaboration in strategic change situations.

Another limitation to this research concerns the resource factors incorporated into the model. Our measures relating to a range of capabilities and types of assets factored into 
only two capabilities and a singe asset factor. A range of items relating to production, procurement, and workforce capabilities did not load on any factors in the exploratory factor analysis. Improving the measures relating to a firm's underlying capabilities and assets may be able to shed even further light on their role in effecting strategic change and changes in supply chain structures.

Given these limitations, there is ample room for future research to further clarify our understanding of how a firm's resources impact a firm's strategic initiatives and supply chain relationships. This research has provided a first glimpse into this complex issue that will hopefully spur additional research activity in this area.

\section{References}

Alreck, Pamela L., and Robert B. Settle, 1995. The survey research handbook $2^{\text {nd }}$ ed.,

Richard D. Irwin, Inc., Homewood, Illinois.

Amit, Raphael, and Paul J.H. Schoemaker, 1993. Strategic assets and organizational rent, Strategic Management Journal, 14(1), 33-46.

Anderson, James C., and D.W. Gerbing, 1988. Structrual equation model in practice: a review and recommended two step approach, Psychological Bulletin, 103(3), 411-423.

Ansoff, H. I., 1968. Corporate strategy: an analytical approach to business policy for growth and expansion, McGraw-Hill, New York, New York.

Barkema, Alan, and Mark Drabenstott, 1995. Industry note: the many paths of vertical coordination: structural implications for the US food system, Agribusiness, 11(5), 483-492.

Barney, J. B., 1991. Firm resources and sustained competitive advantage, Journal of Management, 17(1), 99-120.

Bentler, Peter M., and Eric J. Wu, 1995. EQS for windows user's guide, Multivariate Software, Inc, Encino, California.

Bowersox, D.J., D.J. Closs, and T.P. Stank, 1999. $21^{\text {st }}$ century logistics: making supply chain integration a reality, Council of Logistics Management, Oak Brook, Illinois.

Cooper, Martha C., Douglas M. Lambert, and Janus P. Pagh, 1997. Supply chain management: more than a new name for logistics, The International Journal of Logisitics Management, 8(1), 1-14.

Day, George S., 1994. The capabilities of market-driven organizations, Journal of Marketing, 57(1), 37-51.

Day, George S. and R. Wensley, 1988. Assessing advantage: a framework for diagnosing competitive superiority, Journal of Marketing, 52(4), 1-20.

Dillman, D.A., 1978. Mail and telephone surveys: the total design method, John Wiley \& Sons, New York, New York.

Dillon, William R., and Matthew Goldstein, 1984. Multivariate analysis: methods and applications, John Wiley and Sons, Inc., New York, New York.
Drucker, Peter, 1973. Management: tasks, responsibilities, practices, Harper \& Row, New York, NewYork.

Ellram, Lisa, 1991. Supply chain management: the industrial organisation perspective, International Journal of Physical Distributin \& Logistics Management, 21(1), 13-22.

Fornell, Claes, and David F. Larcker, 1981. Evaluating structural equation models with unobservable variables and measurement error, Journal of Marketing Research, 18(February), 39-50.

Fisher, Marshall L., 1997. What is the right supply chain for your product?, Harvard Business Review, 75(2), 105-116.

Gerbing, David W., and James C. Anderson, 1988. An updated paradigm for scale development incorporating unidimensionality and its assessment, Journal of Marketing Research, 25(May), 186-192.

Grant, Robert M., 1991. The resource-based theory of competitive advantage: implications for strategy formulation, California Management Review, 33(3), 114-135.

Gupta, Ashok K., and David Wilemon, 1996. Changing patterns in industrial r\&d, Journal of Product Innovation Management, 13, 497-511.

Gupta, Ashok K., David Wilemon, and Kwaku Atuahene-Gima, 2000. Excelling in r\&d, Research Technology Management, 43(3), 52-58.

Hair, J.F., Jr., R.E. Anderson, R.L. Tatham, and W.C. Black, 1995. Multivariate data analysis with readings $4^{\text {th }}$ ed., Prentice Hall, Englewood Cliffs, New Jersey.

Hall, Richard, 1993. A framework linking intangible resources and capabilities to sustainable competitive advantage, Strategic Management Journal, 14(8), 607-618.

Hamel, G. and C.K. Prahalad, 1994. Competing for the future, Harvard Business Review, 72(4), 122-130.

Hansen, G. and B. Wernerfelt, 1989. Determinants of firm performance: the relative importance of economic and organizational factors, Strategic Management Journal, 10(5), 399-411.

Hart, Stuart L., 1995. A natural-resource-based view of the firm, Academy of Management Review, 20(4), 986-1014.

Johnson, G. and K. Scholes, 1999. Exploring corporate strategy, Prentice Hall Europe,

Harlow, England.

Kohli, Ajay K., and Bernard J. Jaworski, 1990. Market orientation: the construct, research propositions, and managerial implications, Journal of Marketing, 54(April), 1-18.

Learned, E. P., C. R. Christensen, K. R. Andrews, and W. Guth, 1969. Business policy: text and cases, Richard D. Irwin, Inc., Homewood, Illinois.

Leonard-Barton, D., 1992. Core capabilities and core rigidities: a paradox in managing new product development, Strategic Management Journal, 13(special issue), 111-125.

Nunnally, J.C., 1978. Psychometric theory $2^{\text {nd }}$ ed., McGraw-Hill Book Company, New York, New York. 
O'Keefe, M., 1997. Supply Chain Management, Agricultural Science, 10(3), 29-32.

Porter, Michael E., 1980. Competitive strategy, Free Press, New York, New York.

Porter, Michael E., 1996. Operational effectiveness is not strategy, Harvard Business Review, 74(6), 61-78.

Prahalad, C.K. and G. Hamel, 1990. The core competence of the corporation, Harvard Business Review, 68(3), 79-91.

Ragatz, Gary L., Robert B. Handfield, and Thomas V. Scannell, 1997. Success factors for integrating suppliers into new product development, Journal of Product Innovation Management, 14(3), 190-202.

Selznick, P., 1957. Leadership in administration, Harper \& Row, New York, New York.

Sharma, Subhash, 1996. Applied multivariate techniques, John Wiley \& Sons, Inc., New York, New York.

Slater, Stanley F., and John Narver, 1993. Product-market strategy and performance: an analysis of the miles and snow strategy types, European Journal of Marketing, 27(10), 33-51.

Snow, Charles C., and Lawrence G. Hrebiniak, 1980. Strategy, distinctive competence, and organizational performance, Administrative Science Quarterly, 25(June), 317-336.

Suarez, Fernando F., Michael A. Cusumano, and Charles H. Fine, 1995. An empirical study of flexibiltiy in manufacturing, Sloan Management Review, 37(1), 25-.

Sujan, Harish, Barton A. Weitz, Nirmalya Kumar, 1994. Learning, orientation, working smart, and effective selling, Journal of Marketing, 58(3), 39-.

Teece, David and Gary Pisano, 1998. The dynamic capabilities of firms: an introduction. In: Giovanni Dosi, David J. Teece, and Josef Chytry (editors), Technology, Organization, and Competitiveness - Perspectives on Industrial and Corporate Change, Oxford University Press, Great Britain, pp.193-212.

Treacy, Michael and Fred Wiersema, 1995. The discipline of market leaders, Addison-Wesley Publishing Company, Reading, Massachusetts.

Tzelgov, J., and A. Henik, 1991. Suppression situations in psychological research: definitions, implications, and applications, Psychological Bulletin, 109, 524-536.

Vickery, Shawnee K., Cornelia Droge, and Robert E. Markland, 1993. Production competence and business strategy: do they affect performance?, Decision Sciences, 24(2), 435-455.

Vorhies, Douglas W., and Michael Harker, 2000. The capabilities and performance advantages of market-driven firms: an empirical investigation, Australian Journal of Management, 25(2), 145172.

Wernerfelt, Birger, 1984. A resource-based view of the firm, Strategic Management Journal, 5(2), 171-180.

Wisner, Joel D., and Keah ChoonTan, 2000. Supply chain management and its impact on purchasing, Journal of Supply Chain Management, 36(4), 33-42. 


\section{Appendix}

Factor loadings, chronbach alphas, and item listings

\begin{tabular}{|c|c|c|c|c|c|c|}
\hline & \multicolumn{3}{|c|}{$\begin{array}{l}\text { Capabilities } \\
\text { and assets }\end{array}$} & \multicolumn{2}{|c|}{$\begin{array}{l}\text { Dynamic } \\
\text { capabilities }\end{array}$} & \multirow{2}{*}{$\begin{array}{l}\text { Environment } \\
\mathrm{CI}\end{array}$} \\
\hline & TC & AS & MC & CC & SC & \\
\hline $\begin{array}{l}\text { Reliability } \\
(\alpha)\end{array}$ & 0.77 & 0.64 & 0.61 & 0.71 & 0.70 & 0.68 \\
\hline \multicolumn{7}{|l|}{ Factor } \\
\hline TC1 & .825 & & & & & \\
\hline TC2 & .635 & & & & & \\
\hline TC3 & .480 & & & & & \\
\hline AS1 & & .580 & & & & \\
\hline AS2 & & .573 & & & & \\
\hline MC1 & & & .545 & & & \\
\hline MC2 & & & .518 & & & \\
\hline MC3 & & & .493 & & & \\
\hline CC1 & & & & .727 & & \\
\hline CC2 & & & & .600 & & \\
\hline CC3 & & & & .499 & & \\
\hline SC1 & & & & & .624 & \\
\hline $\mathrm{SC} 2$ & & & & & .562 & \\
\hline $\mathrm{SC} 3$ & & & & & .537 & \\
\hline CI1 & & & & & & .812 \\
\hline CI2 & & & & & & .770 \\
\hline CI3 & & & & & & .732 \\
\hline
\end{tabular}

Technology capabilities (TC)

1. Our firm has the R\&D capability develop or acquire, and commercialise new process technologies

2. Our firm has the R\&D capability develop or acquire, and commercialise new product technologies

3. Our firm uses technology that allows our operations to effectively produce a wide range of products and services

Assets (AS)

1. Our firm has access to or holds valuable patents, licenses, technology or know-how

2. Our firm owns or has preferential access to assets such as brand names and trademarks
Marketing capabilities (MC)

1. Our firm can efficiently distribute our products/services to existing markets

2. Our firm can identify additional needs of our existing customers

3. Our firm is not able to distribute new and different products/services (reverse)

Customer collaboration (CC)

1. Our firm develops strategic plans jointly with our customers

2. Our firm has linked information systems with those of our customers

3. Our firm shares information about operational issues with our customers

Supplier collaboration (SC)

1. Our firm develops strategic plans jointly with our suppliers

2. Our firm shares common goals with our suppliers

3. Our firm has developed joint programmes and activities with our suppliers

Competitive intensity (CI)

1. In our industry competition is intense

2. Price competition is typical in our industry

3. In our industry actions are frequently undertaken that increase competition

Product-mix change

1. During the last two years, our firm has introduced new products/services that were unrelated to products/services we dealt with previously

Process change

1. During the last two years, our firm has established entirely new and unrelated operations utilising new processes or technologies

Supplier change

1. During the last two years, our firm has established a new key supplier relationship in a market our firm already operated in

Customer change

1. During the last two years, our firm has established a new key customer relationship in a market our firm already served 